\title{
Nexus of Institutional Quality and Stock Market Development: Long-Run Relationships in Dynamic Heterogeneous Panel
}

\author{
Muhammad Saeed Meo ${ }^{1}$ \\ Ramzan $\mathrm{Ali}^{2}$ \\ Bilal Aziz Poswal ${ }^{3}$ \\ Mubbshar Ali
}

\begin{abstract}
The current study is intended to analyze the relationship between stock market development and institutional quality. The study is based on the evidence of VISTA alliance for the period of 1984 to 2012. The outcomes of the panel ARDL (PMG) revealed that high regulatory quality, government effectiveness and rule of law, positively affect stock market development in the long-run. While political stability and control over corrupt practices have a significantly negative effect on stock market development. This study provides robust evidence that institutional quality plays a critical role in stock market development in any economy. However, governments should motivate employees to work with motivation by giving rewards, so that corrupt practices can be reduced.
\end{abstract}

JEL Classification: 611, G15, G18

Keywords: Stock Market Performance, Political Stability, Government Effectiveness, Regulatory Quality, Rule of Law, Control of Corruption

\section{INTRODUCTION}

The current study has been carried out to analyze the nexus between stock market development and institutional quality (quality of governance). The term governance is used here to refer to the institutional actions that deal with the regularization of financial institutions in an economy. Evidence has however demonstrated that governess and securities exchange execution is fairly indivisible; along these lines recommending they both go parri-passu. An improvement in institutions which are responsible for the administration of stock market is the base of stock market development. According to Aggarwal et al. (2005) it is evident from an ample body of research that countries with insignificant legal and corporate administration system usually attract lower investment. As exposed by Hooper et al. (2009) agency and transaction costs, which are the major issues, can be alleviated through improved and enhanced quality of governance, which will alternatively lead to significant increase in shareholders return.

Further, it is evident from the stock market analysis that countries and firms with an effective level of governance get a relatively high stock market rating. Similarly, countries that practice standard governance system are observed having a relatively high price market ranking. Moreover, after the financial crises, reports of countries with poor and volatile stock market showed that corporate governance practices are abused in countries that have poor governance sceneries.

1- The Superior College, Lahore, Pakistan Email: saeedk8khan@gmail.com

2- The University of Lahore.

3- The University of Lahore.

4- University of the Punjab.

JISR-MSSE

Volume 16

Number 2

July-December 2018 
The VISTA alliance, which refers to Vietnam, Indonesia, South Africa, Turkey, and Argentina, is a gathering of developing markets that while are clearly not on an indistinguishable size level from huge countries, for example, India and China, are extensive markets that are ready to develop rapidly in the coming years. These countries, for the most part, have a young working population, political security, and surging levels of consumption. Unluckily, the said countries are less developed from both a financial and domestic viewpoint than their BRIC cousins as VISTA countries, for the most part, have a weaker investment in infrastructure and more noteworthy stock market volatility, due in vast part to their generally undeveloped nature (Dutrame, 2011). According to a scholarly report, VISTA economies are expected to expand 28 times by 2015 (Embassy, 2017).

Present work significantly contributes to the existing literature on the current area of interest in terms of; first in the current study has taken into consideration the impact of country-level governance system on stock market performance, which was totally ignored in early studies as they have only taken into consideration firm-level governance. Secondly, most relevant data is being utilized to examine the impact of quality governance on stock market development for the VISTA economies, which escaped scholarly attention.

The rest of the study is arranged in the following way. Existing literature review on quality governance and stock market development is underlying in section 2 . The data source and methodology part is discussed in section 3 . While section 4 consists of data analysis and interpretation. Finally, section 4 covers conclusion.

\section{LITERATURE REVIEW}

Stock market performance is considered as the best indicator for the financial position of an economy. Gaining significant trust of the stockholders is the best way of improving the stock market performance of the country. As per the investor sentiments, they are motivated to invest funds in stock markets, where the economic system provides a favorable environment to stock market practices. Similarly, Hooper et al. (2009) exposed those countries that have developed strong and effective governance (institutional quality) system, experience significant growth in shareholder's earnings in terms of lower agency and transaction cost.

\section{Empirical Studies on Governance Quality}

According to Porta et al. (1997) significant enhancement of a country organizational performance along with good accountability standards are positively correlated with remarkable trust on equity financing by investors. Legal factors particularly control of the corporate resources occupied by managers allow shareholders to screen administrators at lower costs. Early research on governess determined firm-level association's costs rising up out of the proprietorship and control depiction structure of firms. As early literature focuses only on firm-level governance while current literature follows another direction and many researchers started work on national level governance.

Contrary to the previous studies that have focused on firm-level governance contemporary work carried out by (Porta et al., 1997; 1998; Shleifer \& Wolfenson, 2000; Ball et al., 2000) has focused on country-level governance. It was speculated that in the end, the most ideal approach to actualize contracts among chiefs and shareholders was through legitimate movement or something to that effect. Pioneering work in the current area of interest was carried out by Jensen and Meckling (1976) however their study was limited in scope, based on

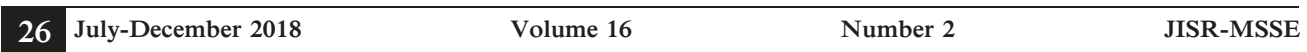


the fact that it has only taken into consideration firm-level governance and they have reached to the conclusion that agency cost raised as a result of interest, conflicts between managers and shareholders.

A study carried out by Ajide (2014) tried to analyze the relationship between stock market performance and governance quality for the Nigerian economy. His analysis exposed that control over corrupt practices and effective type of government system is positively and significantly linked with stock market performance. Similarly, an attempt by Pagano and Lombardo (2000) tries to scientifically investigate the relationship between institutional environment quality and return on equity for a number of developed and emerging economies. Their analysis confirmed a statistically significant and positive relationship between projected variables.

Hooper et al. (2009) have also reached the same conclusion that high quality of institutional environment within a country leads to improvements in stock market performance. Similarly, Asongu (2012) analyzed stock market performance and governance quality relationship for African economies. His study suggests that governance quality and market performance are positively linked. Further, he claimed that control over corruption, fair accountability, and government effectiveness results in the significant development of stock market performance.

\section{DATA AND METHODOLOGY}

To statistically investigate the relationship among the stated variables, panel time series data set has been utilized over the period of 1984 to 2012 for Argentina, Indonesia, South Africa, and Turkey. The economy of Vietnam is not taken into consideration, based on the fact that the data for the desired time period is not available. Total of 116 observations are utilized, which are sufficient for panel data regression analysis. Data for the analysis has been extracted from two sources i.e. observation on quality of governance for the economies under investigations are taken from International Country Risk Guide (ICRG) and data on the performance of stock market are collected from Federal Reserve Economic Data (FRED). For the current analysis Stock Market Capitalization has been used as the depended variable while Government Effectiveness, Political Stability, Control of Corruption, and Rule of Law are included as independent variables. It is expected that all the proposed independent variables have a positive and significant relationship with stock market development.

The general functional form of the model is below.

$S M C=f(P S, G E, R Q, R L, C C)$ Eq.1

Table 1

Description of the projected variables and sources

\begin{tabular}{|c|c|c|c|}
\hline Variables & Description & Units & Sources \\
\hline$\overline{S M C}$ & Stock market capitalization & $\%$ to $G D P$ & FRED \\
\hline$P S$ & Political stability & Index & $I C R G$ \\
\hline$G E$ & Govt.effectiveness & Index & $I C R G$ \\
\hline$R Q$ & Regulatory Quality & Index & $I C R G$ \\
\hline$R L$ & Rule of Law & Index & $I C R G$ \\
\hline$C C$ & Control of Corruption & Index & $I C R G$ \\
\hline
\end{tabular}




\section{Econometrical Model}

$$
s m c_{i t}=\beta_{0}+\beta_{1}\left(p s_{i t}\right)+\beta_{2}\left(g e_{i t)}+\beta_{3}\left(r q_{i t)}+\beta_{4}\left(r l_{i t)}+\beta_{5}\left(c c_{i t)}+\mu_{i t} \ldots \ldots \ldots . . . \mathrm{Eq} .2\right.\right.\right.\right.
$$

Where:

$\begin{array}{llll}\mathrm{SMC} & =\text { Stock market capitalization } & \text { PS } & =\text { Political stability } \\ \mathrm{GE} & =\text { Government effectiveness } & \mathrm{RQ} & =\text { Regulatory quality } \\ \mathrm{RL} & =\text { Rule of law } & \mathrm{CC} & =\text { Control of corruption } \\ i & =\text { Country in panel } & t & =\text { Time Period }\end{array}$

$\beta 1, \beta 2, \beta 3, \beta 4$ and $\beta 5=$ Partial slope coefficients.

\section{Panel Unit Root}

Prior to utilizing time series data for analysis, it is recommended to check for the stationarity of all variables under consideration to keep the model from calculating a spurious relationship. Numbers of tests are available for testing panel unit root hypothesis (Maddala \& Wu, 1999; Hadri, 2000; Breitung, 2001; Levin et al., 2002; Pesaran et al., 2003; Pesaran, 2007). These test can rightly be classified into two generations (Hurlin \& Mignon, 2005; Breitung \& Pesaran, 2008). It is assumed by the first generation panel unit root tests that cross-sections are independent of one another, while the second generation tests for panel unit root assumes that cross-sections are dependent (Kahia et al., 2016). The study at hand employed various first generation panel unit root tests including LLC (LLC, 2002) and IPS (IPS, 2003). We employed only first generation unit root tests because table 4.3 confirmed that cross-sections are independent.

Levin, Lin and Chu panel unit root test also known as (LLC, 2002) is based on the following equation.

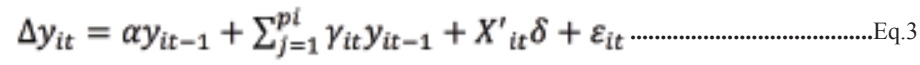

\section{Panel ARDL (PMG Estimation)}

The current work is intended to scientifically analyze the effect of determinants of quality governance (institutional quality) on the performance of the stock market for the vista economies. Panel ARDL, a recently developed approach by Pesaran and Shin, (1999) has been utilized in the current work. ARDL model with Cointegration presented by Pesaran and Smith (1995), Pesaran (1997) and Pesaran and Shin (1999) as a modern technique to extract short -run and long -run relationship. However, Johansen (1995) and Philipps and Bruce (1990) claimed that long run association only existed in Cointegration only between integrated factors. However, Pesaran and Shin (1999) argued about the advantageous of Panel ARDL (mg \& pmg), first they argued that MG and PMG estimators do not require Cointegration test. Autoregressive Distributed Lag model has been used based on its desirable advantages over other techniques to measure the long-run relationship. Firstly, this approach does not compel to researchers regarding stationary of series, panel ARDL (PMG) model can be applied irrespectively to the integration of order either variables are included of $\mathrm{I}(0), \mathrm{I}(1)$ or mixture of $\mathrm{I}(0) \&(1)$ (Pesaran, Shin, \& Smith, 1999). Therefore, in MG and PMG pre-unit root testing is not required. The second advantage of ARDL model is that it takes difference lags to identify the process of data generating from a general to a particular framework of modeling

28 July-December $2018 \quad$ Volume $16 \quad$ Number $2 \quad$ JISR-MSSE 
(Laurenceson and Chai, 2003). Further, the ARDL model produce more efficient long-run coefficients, diagnostic test are also more reliable (Gerrard \& Godfrey, 1998). Moreover, ARDL is the most appropriate technique in case of small sample size (Ajide, 2014). Finally, MG and PMG estimators resolve the endogeneity issue as well ( Islam et al., 2014). The PMG estimator produces short-run coefficients, intercept, and speed of adjustment separately for all cross-sections included in the panel. However, this estimator restricts long-run coefficients slopes homogeneous for all countries included in the panel. The pooled mean group estimation is performed according to the following equation.

$$
\text { lnsmc }_{i t}=\sum_{j=1}^{p} \lambda_{i j} \operatorname{lnsmc}_{i, t-j}+\sum_{j=o}^{q} \delta_{i j}^{\prime} X_{i, t-j}+\mu_{i}+\varepsilon_{i t} \ldots \ldots \ldots \ldots . . . \mathrm{Eq} .4
$$

In the equation $01 \mathrm{i}$ denotes cross-sectional unit, t indicates time period, J denotes optimal lags, $\boldsymbol{X}_{i t}$ denotes independent variables, for example, $P S, G E, R Q, R L$ and $C C$, and $\boldsymbol{\mu}_{i}$ indicates fixed effects. In addition, $p$ and $q$ indicate the panel could be unbalanced. The above equation can be written as by re-parameterization in form of ECM.

The error correction equation written is followed by grouping the variables in level.

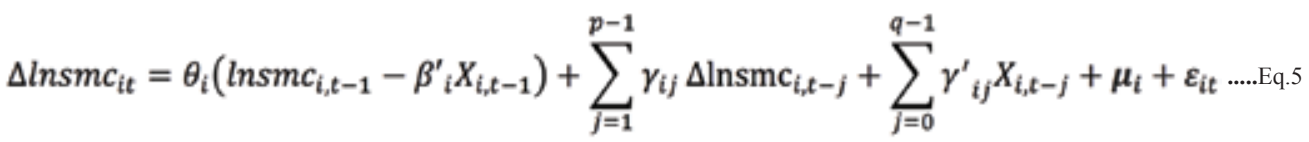

$\theta_{i}$ Indicates long-run equilibrium association between $Y_{i t}$ and $X_{i t}$, while $\beta_{i}^{\prime}$ are the long-run parameters. The $\theta_{i}$ ECT indicates the speed of adjustment, which tells about the speed of convergence of dependent variable towards long-run equilibrium due to shock in explanatory variables. A negative and significant value of $\theta_{i}$ shows long-run causality among dependent and independent variables. There is one restriction of PMG estimator that is long run coefficients remain the same across countries. Therefore

$\Delta l n s m c_{i t}=\theta_{i}\left(\operatorname{lnsmc}_{i, t-1}-\beta^{\prime}{ }_{i} X_{i, t-1}\right)+\sum_{j=1}^{p-1} \gamma_{i j} \Delta \operatorname{lnsmc}_{i, t-j}+\sum_{j=0}^{q-1} \gamma_{i j}^{\prime} X_{i, t-j}+\mu_{i}+\varepsilon_{i t} \ldots . . . \mathrm{Eq} .6$

All the dynamics and error correction terms are allowed to vary.

\section{Results and Analysis}

\section{Table 4.2}

Descriptive statistics

\begin{tabular}{llllll}
\hline Description & LNSMC & LNBQ & LNCC & LNPS & LNRQ \\
\hline Mean & 3.266006 & 0.860999 & 0.972777 & 1.842236 & 1.890293 \\
Median & 3.189101 & 0.693147 & 0.949081 & 1.945910 & 1.915678 \\
Maximum & 5.547121 & 1.386294 & 1.791759 & 2.397895 & 2.397895 \\
Minimum & -0.183478 & 0.223144 & -1.098612 & 1.000000 & 1.203973 \\
Std. Dev. & 1.375078 & 0.251861 & 0.493145 & 0.387221 & 0.272570 \\
Skewness & -0.312248 & 0.807217 & -1.502348 & -1.018505 & -0.264439 \\
Kurtosis & 2.903796 & 2.683113 & 7.273174 & 3.203136 & 2.635742 \\
Jarque-Bera & 1.896445 & 12.18067 & 128.4820 & 20.25493 & 1.993251 \\
Probability & 0.387429 & 0.002265 & 0.000000 & 0.000040 & 0.369123 \\
\hline
\end{tabular}

\begin{tabular}{llrl}
\hline JISR-MSSE & Volume 16 & Number 2 & July-December 2018 \\
\hline
\end{tabular}


Table 4.2 document descriptive statistics of the variables included in the study. Significant difference can be observed in countries based on the variations in extreme values of stock market development. These variations clearly suggest that some of the countries included in the analysis have a developed stock market system, while other has a less developed stock market system. Further, the descriptive statistics for the quality of governance suggests that economies included in the study have a different degree of governance system. Jarque-Bera test of normality exposed that only stock market development and regulatory quality variables are normally distributed, while other variables included in the model are not normally distributed.

Table: 4.3

Residual cross-section dependence test

\begin{tabular}{lll}
\hline Test & Statistic & Prob. \\
\hline Breusch-Pagan LM & 4.235316 & 0.2371 \\
Pesaran scaled LM & -0.720429 & 0.4713 \\
Pesaran CD & -0.248673 & 0.8036 \\
\hline
\end{tabular}

Table 4.3 refers to the cross-sectional dependence of residual. The results confirming that the cross sections are independent.

Table: 4.4

Panel unit root tests

\begin{tabular}{lllll}
\hline Variables & \multicolumn{2}{c}{ Levin, Lin \& Chu t* } & \multicolumn{2}{l}{ Im, Pesaran and Shin } \\
\hline Lnsmc & $1(0)$ & $1(1)$ & $1(0)$ & $1(1)$ \\
& 0.23911 & -2.64015 & -0.27033 & -7.67029 \\
Lnge & $(0.59)$ & $(0.00)^{*}$ & $(0.39)$ & $(0.00)^{*}$ \\
& 0.22231 & -4.02610 & 0.15674 & -2.71300 \\
Lncc & $(0.58)$ & $(0.00)^{*}$ & $(0.56)$ & $(0.00)^{*}$ \\
& -0.21634 & -4.17840 & -0.30788 & -3.53856 \\
Lnps & $(0.41)$ & $(0.00)^{*}$ & $(0.37)$ & $(0.00)^{*}$ \\
& -0.76949 & -4.19303 & -0.94529 & -5.98689 \\
Lnrq & $(0.22)$ & $(0.00)^{*}$ & $(0.17)$ & $(0.00)^{*}$ \\
& -1.05311 & -6.90118 & -1.18984 & -5.69489 \\
Lnrl & $(0.14)$ & $(0.00)^{*}$ & $(0.11)$ & $(0.00)^{*}$ \\
& -0.52303 & -4.90172 & -0.86583 & -4.36295 \\
& $(0.30)$ & $(0.00)^{*}$ & $(0.19)$ & $(0.00)^{*}$ \\
\hline
\end{tabular}

Note :() represents probability value* refers to $1 \%$ level of significance

Table 4.4 revealing unit root tests output, the study at hand confirms that all the variables reject alternative hypothesis of no unit root at a level, but after taking their first difference, all variables become stationary. Normally pre-unit root checking is not required for the ARDL approach (Sezgin and Yildirim, 2002) but there is one limitation of autoregressive distributed lags model that we can't apply ARDL model in the presence of second difference variable i.e. I(2). Therefore, still, it is important to check stationery to avoid from 1(2) (Ibrahim, 2015). In the current case, all of the projected variables become stationary at first difference and hence meets the precondition for applying ARDL.

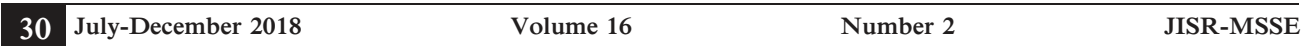


Table: 4.5

Long-Run Coefficients of Panel ARDL $(P M G)(1,1,1,1,1,1)$ Model Dependent Variable (lnsmc)

\begin{tabular}{lllll}
\hline Variables & Coefficient & Std. Error & T. Statistic & Prob. \\
\hline Lnge & 1.122417 & 0.361480 & 3.105057 & $0.0027^{*}$ \\
Lncc & -0.429993 & 0.193792 & -2.218830 & $0.0296^{* *}$ \\
Lnps & -0.322907 & 0.151333 & -2.133745 & $0.0362^{* *}$ \\
Lnrq & 1.693145 & 0.309595 & 5.468906 & $0.0000^{*}$ \\
Lnrl & 0.314623 & 0.176516 & 1.782400 & $0.0788^{* * *}$ \\
\hline
\end{tabular}

Note: $* * * \& * * *$ refers to $1 \%, 5 \% \& 10 \%$ level of significance respectively.

The results of table 4.5 explicitly suggest that government effectiveness is positively and significantly linked with stock market performance in the long-run, with 5\% exact probability value. The magnitude of partial slope coefficient for government effectiveness suggests that a $1 \%$ increase in government effectiveness will result in a $1.12 \%$ improvement in stock market performance. The regularity quality and law and order also have a significant and positive association with the stock market performance at 5\% and 10\% level of significance respectively. The coefficient values regularity quality and law and order indicate that $1 \%$ increase in RQ and RL lead to increase $1.6 \%$ and $0.31 \%$ respectively in stock market performance. These findings are in line with (Lombardo \& Pagano, 1999; Asongu, 2012; Ajide, 2014; Matthew, 2015). On the other hand, control of corruption and government stability negatively and significantly linked with the stock market performance at $5 \%$ level of significance in long run. The partial slope coefficients for both variables suggests that $1 \%$ change in control of corruption and government stability will lead to $0.24 \%$ and $0.32 \%$ changes in stock market performance in opposite direction. The negative relationship between control of corruption and stock market performance also investigated by (Ayaydın \& Baltacı, 2013; Sergi et al., 2015).

It is worth mentioning that resultant relationship among control of corruption, government stability, and stock market performance is against the expectation, however, there are some previous studies that have reached the same conclusion. As stated by Leff (1964) and Lui (1985) that corruption fueled the stock the market growth. Further, Leff (1964) argued that in economies with strict regulation forced by the government, corruption increases economic development because "Enables the private's agents to buy their way out of politically imposed inefficiencies". Ahlin and Pang (2008) guarantee that corruption raises the requirement for liquidity and in this way makes monetary enhancements more intense.

Table: 4.6

Error Correction Representation of the Selected Panel ARDL (PMG) $(1,1,1,1,1)$ Model Dependent Variable (lnsmc)

\begin{tabular}{lllll}
\hline Regressor & Coefficient & Std. Error & T. statistic & Prob. \\
\hline C & -0.071 & 0.212 & -0.336 & 0.737 \\
$\Delta$ Inge & 0.071 & 0.402 & 0.186 & 0.852 \\
$\Delta$ Incc & -0.222 & 0.091 & -2.280 & $0.025^{* *}$ \\
$\Delta$ Inps & 0.231 & 0.131 & 1.733 & $0.087^{* * *}$ \\
$\Delta$ Inrq & -0.187 & 0.162 & -1.166 & 0.248 \\
$\Delta$ Inrl & -0.142 & 0.401 & -0.349 & 0.727 \\
ECM $(-1)$ & -0.566 & 0.216 & -2.624 & $0.010^{*}$ \\
\hline
\end{tabular}

Note: $*, * *, \& * * *$ refers to $1 \%, 5 \% \& 10 \%$ level of significance respectively.

\begin{tabular}{llll|l}
\hline JISR-MSSE & Volume 16 & Number 2 & July-December 2018 & 31
\end{tabular}


Furthermore, in short run control of corruption and regulatory quality demonstrate a negative association with stock market performance, while government stability in long run associates with stock market performance positive and significant at $10 \%$ level of significance. However, rest of the variables are insignificantly associated with stock market performance, the error correction terms tell about the speed of adjustment as $56 \%$. Other researchers, noticed that a significant Error correction term having a negative sign is an approach to demonstrate the long-run association is steady. The deviation of stock market development from short-run to the Long-run is rectified by $54 \%$ every year.

Table: 4.7

Panel Homogeneous Causality Test

\begin{tabular}{|c|c|c|c|}
\hline Variables & F-statistics & Probability & Decision \\
\hline lnsme $\Rightarrow$ lnge & 2.43892 & $0.0338 * *$ & Uni directional causality \\
\hline lnce $\Leftarrow / \Rightarrow$ lnsme & 0.7773 & 0.6447 & No causality \\
\hline lnps $\Leftarrow / \Rightarrow$ lnsme & 0.2270 & 0.9668 & No causality \\
\hline $\ln s m c \Rightarrow \ln r q$ & 2.0610 & $0.06775 * * *$ & Uni directional causality \\
\hline $\operatorname{lnsm} c \Rightarrow \ln r l$ & 2.6820 & $0.0204 * *$ & Uni directional causality \\
\hline
\end{tabular}

Note: $*, * * \& * * *$ refers to $1 \%, 5 \% \& 10 \%$ level of significance respectively.

Results for the short-run homogeneous panel causality are documented in table 4.7; the outcome suggests that uni-directional causality is running from market performance to government effectiveness, which means that higher the stock market development leads to higher government effectiveness. Similarly, a uni-directional causal relationship has been found, running from stock market performance to regulatory quality and law and order situation. However, no causal relationship has been found among policies to control corruption, government stability, and stock market performance.

\section{CONCLUSION}

The current study is intended to analyze the performance of the stock market in terms of elements of quality of governance (institutional quality), the study is based on the evidence of VISTA alliance for the period of 1984 to 2012. In the current research work stock market capitalization has been used as an indicator of stock market performance. To determine the long and short run relationship among the projected variables, panel data ARDL (PMG) technique has been utilized in the current study. Further, panel homogeneous causality test has been performed to determine the direction of causality between the dependent variable and independent variables. The output of ARDL model revealed that there is a statistically significant and positive relationship among regulatory quality, government effectiveness, rule of law, and stock market development. It implies that improvement in rule of law, regulatory quality, and performance of stock market increases stock market performance. However, control of corruption and government stability have a negative impact on stock market performance, it implies that increase in control of corruption and government stability leads to decrease in stock market development. However, the adverse impact of control of corruption is not suitable for financial or business action.it means that the there is a shadow economy where the financial activities go side by side with black money which needs special policy vista to control the underground economy. A worth mentioning point about the economies under consideration is that majority of the rich people generate their wealth through corruption inclusive illegal means. Logically a larger portion of their investment funds is composed of

32 July-December $2018 \quad$ Volume $16 \quad$ Number $2 \quad$ JISR-MSSE


income earned through illegal means. Consequently, implementation of any policy measure concern with corruption control will lead to decrease in their investment funds and will alternatively pose a negative effect of stock market. Hence, to promote governance quality and stock market development. The government should encourage investors by formulating of such kind of policies, which could create trust among investors for stock market investment.

\section{REFERENCES}

Aggarwal, R., L.Klapper \& P.D.Wysocki (2005). Portfolio preferences of foreign institutional investors. Journal of Banking \& Finance, 29, 2919-2946.

Ahlin, C., \& Pang, J. (2008). Are financial development and corruption control substitutes in promoting growth?. Journal of Development Economics, 86(2), 414-433.

Ajide, K. B. (2014). Quality of governance and stock market performance: the Nigerian experience. Journal of Economics and Development Studies, 2(2), 501-522.

Asongu, S. A. (2012). Government quality determinants of stock market performance in African countries. Journal of African Business, 13(3), 183-199.

Ayaydın, H., \& Baltacı, N. (2013). Corruption, banking sector, and stock market development: A panel data analysis. Management, 94, 99.

Ball, R., Kothari, S. P., \& Robin, A. (2000). The effect of international institutional factors on properties of accounting earnings. Journal of accounting and economics, 29(1), 1-51.

Breitung, J. (2001). The local power of some unit root tests for panel data. In Nonstationary panels, panel cointegration, and dynamic panels (pp. 161-177). Emerald Group Publishing Limited.

Dutrame, E. (2011). "Forget BRIC ETFs: Look to VISTA nations for better opportunities." from http://etfdb.com/2011/forget-bric-etfs-look-to-vista-nations-for-better-opportunities

Embassy, V. (2017). "VISTA economies forecasts skyrocket." from http://www.vietnamembassy-myanmar.org/vnemb.vn/tinkhac/ns070813153208?b_start: int $=10$.

Gerrard, W. J., \& Godfrey, L. G. (1998). Diagnostic checks for single-equation error-correction and autoregressive distributed lag models. The Manchester School, $66(2), 222-237$.

Hadri, K. (2000). Testing for stationarity in heterogeneous panel data. The Econometrics Journal, 3(2), 148-161.

Hooper, V., Sim, A. B., \& Uppal, A. (2009). Governance and stock market performance. Economic Systems, 33(2), 93-116.

Hurlin, C., \& Mignon, V. (2005). A synthesis of unit root tests on panel data. Economy \& forecast, (3), 253-294.

Ibrahim, M. H. (2015). Oil and food prices in Malaysia: a nonlinear ARDL analysis. Agricultural and Food Economics, 3(1), 2. https://doi.org/10.1186/s40100-014-0020-3

Im, K. S., Pesaran, M. H., \& Shin, Y. (2003). Testing for unit roots in heterogeneous panels. Journal of econometrics, 115(1), 53-74.

Islam, M., Kazi, M., \& Tarique, K. M. (2014). CO/sub 2/emission and agricultural productivity in southeast asian region: a pooled mean group estimation. Science Vision, 20(1), 93-99.

Jensen, M. C. and W. H. Meckling (1976). Theory of the firm: Managerial behavior, agency costs and ownership structure. Journal of financial economics, 3(4),305-360.

Johansen, S. (1995). Identifying restrictions of linear equations with applications to simultaneous equations and cointegration. Journal of econometrics, 69(1), 111-132.

\begin{tabular}{llll}
\hline JISR-MSSE & Volume 16 & Number 2 & July-December 2018
\end{tabular} 
Kahia, M., Aïssa, M. S. B., \& Charfeddine, L. (2016). Impact of renewable and non-renewable energy consumption on economic growth: New evidence from the MENA Net Oil Exporting Countries (NOECs). Energy, 116, 102-115.

La Porta, R., Lopez-de-Silanes, F., Shleifer, A., \& Vishny, R. W. (1997). Legal determinants of external finance. The Journal of finance, 52(3), 1131-1150.

Laurenceson, J., \& Chai, J. C. (2003). Financial reform and economic development in China. Edward Elgar Publishing.

Leff, N. 1964. Economic development through bureaucratic corruption, American Behavioral Scientist 8: 8-14.

Levin, A., Lin, C. F., \& Chu, C. S. J. (2002). Unit root tests in panel data: asymptotic and finite-sample properties. Journal of econometrics, 108(1), 1-24.

Lui, F. T. (1985). An equilibrium queuing model of bribery. Journal of political economy, 93(4), 760-781.

Maddala, G. S. and S. Wu (1999). A comparative study of unit root tests with panel data and a new simple test. Oxford Bulletin of Economics and statistics, 61(S1), 631-652.

Matthew, E. T. (2016). Institutional Quality and Stock Market Development in Nigeria-An Application of the Ardl Approach (Doctoral dissertation).

Pagano, M., \& Lombardo, D. (1999). Legal Determinants of the Return on Equity. Centre for Economic Policy Research Discussion Paper, 2275, 64.

Pesaran, M. H. (2007). A simple panel unit root test in the presence of cross-sectiondependence. Journal of applied econometrics, 22(2),265-312.

Porta, R. L., Lopez-de-Silanes, F., Shleifer, A., \& Vishny, R. W. (1998). Law and finance. Journal of political economy, 106(6), 1113-1155.

Pesaran, M. H., \& Smith, R. (1995). Estimating long-run relationships from dynamic heterogeneous panels. Journal of econometrics, 68(1), 79-113.

Pesaran, M. H., Shin, Y., \& Smith, R. P. (1999). Pooled Mean Group Estimation of Dynamic Heterogeneous Panels. Journal of the American Statistical Association, 94(446), 621-634. https://doi.org/10.1080/01621459.1999.10474156

Sezgin, S., \& Yildirim, J. (2002). The Demand for Turkish Defence Expenditure. Defence and Peace Economics, 13(2), 121-128. https://doi.org/10.1080/10242690210973

Shleifer, A., \& Wolfenzon, D. (2002). Investor protection and equity markets. Journal of financial economics, 66(1), 3-27.

Talley, N. J., Phillips, S. F., Bruce, B., Twomey, C. K., Zinsmeister, A. R., \& Melton, L. J. (1990). Relation among personality and symptoms in nonulcer dyspepsia and the irritable bowel syndrome. Gastroenterology, 99(2), 327-333. 